\title{
Strategic Orientation and Organisational Culture in Polish Public Organisations: Insights from the Miles and Snow Typology'
}

Martyna Wronka-Pośpiech, Ph.D. University of Economics in Katowice,

Department of Entrepreneurship and Management Innovation

Prof. Aldona Frączkiewicz-Wronka University of Economics in Katowice,

Department of Public Management and Social Science

\section{Introduction}

In the management of any organisation, the fundamental objective behind undertaking actions is the desire to succeed (Ring, Perry 1985). Contemporary organisations working in turbulent environments are faced with the necessity to meet many complex requirements arising from the fact that they operate in a world without permanent rules, a universal style of management, or a universal recipe for success (Skrzypek 2007). The changing socio-economic situation and the evolution of social needs, particularly the expectations of individuals and families in crisis situations, contribute to new challenges for the social welfare system - including the modification and reorientation from organizing activities primarily related to the allocation of inputs and accurate completion of procedures to

1 The paper is financed under the project „Features and competencies of social entrepreneur researchresults"|"Cechyi kompetencje przedsiębiorcy społecznego-badania empiryczne". Research results are result of the project "Kultura organizacyjna organizacji publicznych"/"Organisational culture in public organisations". 
the achievement of results, including efficiency and effectiveness, and quality of services (Kieżun 2000). The most important aspect of management is continuous adaptation of an organisation's strategy to emerging changes. The current circumstances, characterized by marketization of many services typical of the public sector, lead to a need for new mode of action for managers of the organisations, which provide public services, including social services.

In the literature, one might frequently encounter a statement that the design of the overall strategy is an issue crucial (yet frequently neglected) to the effectiveness of non-profit organisations (i.e. public or social organisations) (Frumkin, Andre-Clark 2000). Both theoreticians and practitioners emphasize that the strategic planning process should reflect specifics of an organisation's functioning in its distinctive setting as much as possible (Courtney 2002, Stone, Bigelow, Crittenden 1999). The correct design of strategy requires familiarity with the specificity of the sector, because an organisation's strategy must be embedded in a particular context of its environment, which determines the key assumptions adopted for the design of the strategy and for the implementation of planned activities. The staff of organisations providing social services is focused on stimulating the activity of people marginalized or threatened with marginalization, and therefore inherently unwilling to take active measures. On the other hand, they are also focused on the search for entities, which will enable this activity and provide continuous support. This approach requires the creation of a series of coalitions and institutional support systems, which causes the need for knowledge of both the entities operating in the environment of organisations providing social services, and of the relationships that govern their functioning within an organisation. Institutional involvement of the organisations, which provide social services, means, on the one hand, supporting the idea of participation in the local community, and on the other hand, in the long term perspective, translates into real economic outcomes, identified in both micro- and macroeconomic perspective. The results of the return to the labour market of the clients previously marginalized or threatened by marginalization should be considered not only in social but also - or perhaps mostly - in economic terms. Well-conducted activation influences a reduction in state expenditure, and, in order to conduct activation well, organisations providing social services need to be properly managed, which involves skilful and realistic design and implementation of strategy. This in turn is achieved through the proper identification of organisational culture, and its potential modification towards the desired direction (Porter 1992). 
The aim of this paper is to examine strategic orientation and organisational culture. We focus our research interest on public organisations providing social services in the scope of social welfare and labour market. Due to the scope of our research social welfare centres and labour offices operating in Upper Silesian conurbation were chosen to be studied.

\section{Relationship between organisational culture and strategic orientation - theoretical background}

Among various typologies of strategic orientation, which might be considered as key ones, are the concepts of R.E. Miles and C.C. Snow (1978) - prospector, analyzer, defender, reactor, and famous Porter's typology - cost leadership, differentiation, cost focus, and differentiation focus. Some of the research on strategic orientation is focused on the relationship between strategic orientation, and an organisation's results (Morgan, Strong 2003; Kaya, Seyrek 2005; Sanchez, Marin 2005; Pleshko 2006; Pleshko, Nickerson 2008; Azhar 2008), whereas others concentrate on the factors influencing it (Zhou, Li 2007). As studies reveal, the basic factors, which may shape strategic orientation, include: environmental factors (market turbulence, technology), organisational factors (organisational structure, organisational culture, and leadership) or institutional ones (government intervention, corporate governance).

An interesting study on the relationship between organisational strategy and organisational culture was conducted by Australian researchers, according to whom culture and strategy condition each other (Baird, Harrison, Reeve 2007). This means that, in order to implement a specific strategy, it is necessary to build proper organisational culture, and that the organisational culture leads to the selection and implementation of a specific strategy of the organisation. To measure organisational culture, the authors used a measurement tool comprising of a set of characteristics illustrating the possible values of the organisation - the so-called organisational culture profile (OCP) (O'Reilly, Chapman, Caldwell 1991). This enables mapping of culture, which takes into account six (originally eight) factors: outcome orientation, detail orientation, supportiveness, innovation, team orientation, and stability. The authors operationalized and measured strategy by means of the aforementioned strategic behavior typology proposed by R.E. Miles and C.C. Snow (1978). The empirical studies conducted among 200 top management members show, among other things, that in the case Prospectors, much more than in the case of Defenders, organisational culture is geared towards outcome orientation and innovation. Defenders, in turn, 
appreciate stability and attention to detail to a greater extent than of Prospectors and Analyzers. This might be justified by the fact that Defenders have to create an atmosphere of stability, because their strategy is based on high efficiency and low cost. In addition, attention to detail combines with such standards of conduct as precision, attention and adherence. On the other hand, stability and attention to detail tend to deprive an organisation of flexibility and innovation. Therefore, an organisation, which intends to implement Defender strategy, must ensure such an organisational culture, in which values such as stability and attention to detail are appreciated. Hence, K. Baird, G. Harrison and R. Reeve's research (2007) reveals that the organisational culture must be consistent and compatible with the strategic orientation, and organisations should seek to adjust their activities to implement the adapted strategy.

Other studies on the relationship between the organisation's strategy and organisational culture were conducted by B. Gupta (2011). These studies were carried out in various sectors of economy, and were based on the strategic behavior typology proposed by R.E. Miles and C.C. Snow (1978), as well as on the competing values model proposed by K.S. Cameron and R.E. Quinn (2003), in which clan, adhocracy, hierarchy, and market cultures are distinguished. As evidenced by B. Gupta, strategy and organisational culture are mutually conditioning, which means that any organisation with a change in strategy must adjust an appropriate organisational culture; otherwise, it is bound to fail in the implementation of the adopted strategy. Organisational culture influences the behaviour of employees and managers, and their behaviour leads to the implementation of strategy. As widely acknowledged, every type of strategic orientation in the typology of R.E. Miles and C.C. Snow is characterized by a different attitude to the environment and the organisation's resources, as well as different success criteria etc., which at the same time means that if a particular business strategy is to be implemented in a successful way, it must be connected to a particular type of organisational culture.

The relationship between organisational culture and strategy is also evident in the context of functional strategies in various areas of an organisation's operation. I.H.S. Chow and S.S. Liu's (2009) research is based on the assumption that the compatibility between organisational culture and strategy leads to better performance of an organisation. The authors hypothesize that the effectiveness of strategy in human resource management (HRM) depends on its compliance with organisational culture and overall strategy of an organisation, and their research confirms that organisational culture is a mediator between the strategy in the field of HRM and organisation's results, as well as employment rotation. 
With regard to organisational culture, the authors rely on the classification proposed by J.E. Wallach (1983), who identifies three types of organisational culture, i.e.: bureaucratic-competitive, supportive and innovative.

The existence of relations between organisational culture and strategy was also sought in the context of market entry strategies (Naranjo-Valencia, JimenezJimenez, Sanz-Valle 2011). As research reveals, organisational culture influences a company's strategy of entering the market, especially in choosing innovation strategy or imitation strategy. As might be expected, innovation strategy requires certain traits and behaviors of an organisation, such as flexibility, openness to change, entrepreneurship, risk acceptance, and tolerance of error, whereas the imitation strategy is associated with control, stability, performance, and precision. Therefore, organisational culture will influence the choice of strategy - between the strategy of innovation and the strategy of imitation. J.C. Naranjo-Valencia, D. Jimenez-Jimenez, R. Sanz-Valle (2011), relying on the competing values model proposed by K.S. Cameron and R.E. Quinn (2003), prove empirically that adhocracy culture is associated with innovative behaviors of an organisation, while hierarchy culture is associated with imitation as a strategy of market entry.

Also, other empirical studies show the existence of relationships between marketing strategy, organisational strategy, and organisational culture (Yarbrough, Morgan, Vorhiesd 2011). According to the researchers, the compatibility between marketing strategy and organisational culture (measured on the basis of competing values model) translates into more value delivered to consumers and their greater satisfaction, which in turn translates into better performance of an organisation. Additionally, S. Fang and J. Wang (2006) establish that both organisational culture and organisational learning affect the strategy of an organisation in terms of production. The authors use the wellknown model of G. Hofstede for measuring organisational culture, and argue that two of the four cultural dimensions have a particularly significant impact on the strategy with regard to production: power distance and individualism. The cited empirical studies also demonstrate the existence of a strong interdependence between strategic orientation and organisational culture, and that the way in which these relationships are formed affects the results of the organisation. Organisational culture is important in that it either restricts or allows the implementation of strategy (Schneider, Schneider 2007). The relationship between culture and strategy is manifested in the fact that certain types of organisational culture determine the formulation and implementation of specific strategies, while particular strategies have an impact on the creation 
of specific types of organisational cultures. Organisational culture affects both the formulation of strategy, and the process of its implementation.

At the stage of formulating strategy, culture affects its selection, whereas in the implementation phase, it might be a factor either stimulating or inhibiting the deployment of the strategy. In the process of formulating strategy, organisational culture represents a point of reference for the people making decisions of a strategic nature. Basic assumptions, norms and values shared by the members of an organisation have a significant impact on how they comprehend and interpret changes occurring both within the organisation, and in its environment. This in turn affects the choice of the strategy of the organisation. Whether the managers will notice the presence of new trends in the market, whether trade liberalization in the sector will be interpreted as a threat or an opportunity, and whether the managers will seek to reduce or increase marketing expenses in the face of declining sales largely depends on the way in which these managers interpret reality, which in turn is strongly dependent on the underlying assumptions, norms and values. Thus, organisational culture defines the way in which managers gather and analyze information coming from both the external environment, and from within the organisation. In addition, organisational culture influences the way of interpreting this information, which determines the choice of a strategic option.

In the phase of strategy implementation, organisational culture might stimulate or inhibit this implementation, which depends on the degree of conformity of the chosen strategy to the underlying assumptions, norms and values. The choice of a particular strategy entails taking certain actions through which it will be executed. If these actions are consistent with the basic assumptions, norms and values, they will be interpreted by the members of the organisation as legitimate and necessary. Therefore, organisational culture legitimizes organisational strategy. If a strategy does not conform with the existing organisational culture, there emerges a risk of problems with its implementation (Schwartz, Davis 1981).

Just as organisational culture influences the process of strategy formulation and implementation, long-term realization of strategy may also influence organisational culture - either strengthen or weaken it. The extent of this impact will depend on whether the strategy is consistent with the norms, values and basic assumptions characteristic for the given culture. For this reason, if a strategy intends to conduct activities consistent with the principles of action (standards, values) of the organisation, this strategy will exert a positive impact on the existing organisational culture, because it will further strengthen its values. 


\section{Organisational culture and strategic orientation in public organisations providing social services - research results}

There are two parts to the research objectives. Firstly, our aim is to explore the current strategic types of public organisations in question. Secondly, we aim to examine the relationship between strategy and organisational culture. The study used purposive sampling, which was dictated by organisational reasons (the criterion of entity availability), and a similar structure and the specificity of activity of the selected entities, as well as the environment in which they operate. Thus, the organisations subjected to the study were Municipal Social Welfare Centres (Miejski Ośrodek Pomocy Społecznej - MOPS) and District Labour Offices (Powiatowy Urząd Pracy - PUP) operating in the cities of the Upper Silesian Metropolitan Union, i.e. Bytom, Chorzów, Gliwice, Dąbrowa-Górnicza, Jaworzno, Katowice, Mysłowice, Piekary Śląskie, Ruda Śląska, Siemianowice Śląskie, Sosnowiec, Świętochłowice, Tychy and Zabrze. In total, the study involved 28 organisations (14 Municipal Social Welfare Centres and 14 District Labour Offices). Data for the study were collected in 2014 through a survey from 10 employees of each of 14 District Labour Offices and 14Social Welfare Centres in Poland. The choice of these two types of providers of social services was dictated by the researchers' conviction about the critical significance of the social services provided by these entities both for the national economy, and for mitigation, combating, and preventing problems of exclusion and marginalization.

One of the objectives of the research was to identify the types of strategic orientation in the studied organisations. According to the concept proposed by C.C. Miles and R.E. Snow, organisations might be characterized by four types of strategic behaviour. These four strategies are referred to as Prospector, Defender, Analyzer and Reactor. Each of these strategies might be said to have a different attitude to innovation (as an organisational phenomenon), the environment, the organisation's resources, and, consequently, each will lead to different results of the organisation's activities. Strategic behaviours as such are usually understood as the composition of decisions through which organisations adapt to the characteristics and variability of the environment (DeSarbo et al. 2005). The assessment of strategic orientation was based on validated instrument comprising 11 questions (Conant et al. 1990; DeSarbo et al. 2005). Each item included 4 answers. Since 10 respondents from each organisation participated in the study, the frequency of answers to each question was counted. In the event of an equal number of indications for the given question, which might signify a lack of clear orientation in terms of a specific characteristic, more than

Strategic Orientation and Organisational

Culture in Polish Public Organisations:

Insights from the Miles and Snow Typology 
one dominant characteristic was determined. On this basis, in relation to the methodology adopted in this area, the occurrence of 4 strategic orientations was established: Prospector - P, Analyzer - A, Defender - D and Reactor - R. In the event of an equal number of indications, proper types of mixed strategies were determined. Table 1 presents the structure of particular types of strategic orientation in the sample.

Table 1. Types of strategic orientation in the studied organisations

\begin{tabular}{|c|c|c|}
\hline Type of strategic orientation & Organisation & Percentage \\
\hline \multicolumn{3}{|c|}{ District Labour Offices } \\
\hline A & 2 & $14.28 \%$ \\
\hline $\mathrm{AD}$ & 1 & $7.14 \%$ \\
\hline $\mathrm{R}$ & 5 & $35.71 \%$ \\
\hline $\mathrm{D}$ & 5 & $35.71 \%$ \\
\hline $\mathrm{D} / \mathrm{R}$ & 1 & $7.14 \%$ \\
\hline \multicolumn{3}{|c|}{ Municipal Social Welfare Centres } \\
\hline $\mathrm{A} / \mathrm{R}$ & 2 & $14.28 \%$ \\
\hline $\mathrm{R}$ & 6 & $42.85 \%$ \\
\hline $\mathrm{D}$ & 4 & $28.57 \%$ \\
\hline $\mathrm{D} / \mathrm{R}$ & 1 & $7.14 \%$ \\
\hline $\mathrm{P}$ & 1 & $7.14 \%$ \\
\hline \multicolumn{3}{|c|}{ Together } \\
\hline A & 2 & $7.14 \%$ \\
\hline $\mathrm{AD}$ & 1 & $3.57 \%$ \\
\hline $\mathrm{A} / \mathrm{R}$ & 2 & $7.14 \%$ \\
\hline $\mathrm{R}$ & 11 & $39.28 \%$ \\
\hline $\mathrm{D}$ & 9 & $32.14 \%$ \\
\hline $\mathrm{D} / \mathrm{R}$ & 2 & $7.14 \%$ \\
\hline $\mathrm{P}$ & 1 & $3.57 \%$ \\
\hline Sum & 28 & $100.00 \%$ \\
\hline
\end{tabular}

Source: own study 
In the studied sample, the Reactor type of strategic orientation dominates (11 organisations). The organisations with this strategic orientation usually have no conscious or coherent strategy, and do not change their attitude depending on the outer pressure. C.C. Miles and Snow R.E. indicate that such organisations are oriented to acting in a short time, and are strongly dependent on the environment (Doty, Glick, Huber 1993). Strong dependence on the environment does not raise major surprise in the case of public entities; however, the lack of strategy, as expressed by the respondents, might be alarming. A considerable part of the sample possesses the Defender type of strategic orientation. Defenders engage in the development of new products or markets to a small extent or not at all, but devote much attention to improving the efficiency, and focus on the tasks emerging in this area. Such organisations rely on centralized decisionmaking, and usually have relatively simple control mechanisms (Snow, Miles, Miles 2005).

In order to assess organisational culture we used the most widespread and used in many empirical studies Cameron and Quinn's model (2003), the Competing Values Framework (CVF), from which four cultures - adhocracy, clan, market and hierarchy - emerge. The purpose of the Organisational Culture Assessment Instrument (OCAI) is to assess six key dimensions of organisational culture. Assessment is based on six questions and each question has four alternatives. Respondents were asked to divide 100 points among these four alternatives depending on the extent to which each alternative is similar to their own organisation. Then, responses were analysed to assess the relationships between strategic orientation and organisational culture. Table 2 presents the relationship between the dominant culture and the types of strategic orientation identified in the studied sample.

Table 2. Types of strategic orientation and organisational culture in the studied organisations

\begin{tabular}{l|c|c|c|c|c}
\hline \multicolumn{2}{c|}{} & \multicolumn{3}{c}{ Organisational Culture } \\
\cline { 3 - 6 } & $\begin{array}{c}\text { Clan } \\
\text { culture }\end{array}$ & $\begin{array}{c}\text { Hierarchy } \\
\text { culture }\end{array}$ & \multicolumn{2}{c}{ Percentage } \\
\hline $\begin{array}{l}\text { Strategic } \\
\text { orientation }\end{array}$ & Analyzer (A) & 2 & - & $7.14 \%$ & - \\
\hline & Analyzer/Defender (A/D) & 1 & - & $3.57 \%$ & - \\
\cline { 2 - 6 } & Analyzer/Reactor (A/R) & 1 & 1 & $3.57 \%$ & $3.57 \%$ \\
\hline
\end{tabular}




\begin{tabular}{l|c|c|c|c|c}
\multirow{2}{*}{} & Reactor (R) & 3 & 8 & $10.71 \%$ & $28.57 \%$ \\
\cline { 2 - 6 } & Defender (D) & 3 & 6 & $10.71 \%$ & $21.42 \%$ \\
\cline { 2 - 6 } & Defender / Reactor (D/R) & 1 & 1 & $3.57 \%$ & $3.57 \%$ \\
\cline { 2 - 6 } In total & Prospector (P) & - & 1 & - & $3.57 \%$ \\
\hline \hline \multicolumn{2}{c}{28} & \multicolumn{2}{c}{$100 \%$} \\
\hline \multicolumn{2}{c}{ Source: own study }
\end{tabular}

Two cultures typical of organisations in question are clan and hierarchy culture. The hierarchy has a traditional approach to structure and control that flows from a strict chain of command as in Max Weber's original view of bureaucracy. Hierarchies have respect for position and power and they often have well-defined policies, processes and procedures. Hierarchical leaders are typically coordinators and organizers who keep a close eye on what is happening. The Clan organisation has less focus on structure and control and a greater concern for flexibility. Rather than strict rules and procedures, people are driven through vision, shared goals, outputs and outcomes. In contrast to hierarchies, clans often have flat organisations and people and teams act more autonomously. Clan leaders act in a facilitative, supportive way and may take on a parental role.

Considering the "pure" strategic types, it might be noticed that hierarchy culture dominates both in Reactor and Defender organisations (8 and 6 organisation), while clan culture occurs in 3 organisations with such types of strategic orientation. Clan culture characterizes two Analyzer organisations, and hierarchy culture was revealed in the case of Prospector (1 organisation). Among the identified "mixed" types, hierarchy culture was found in an organisation that combines Analyzer and Reactor (1 organisation) as well as Defender and Reactor (1 organisation). The same situation occurs in the case of clan culture (1 organisation of the aforementioned mixed types), and also the type which combines Analyzer and Defender (1 organisation) was observed here.

\section{Conslusions}

The last two decades have brought a number of changes in the functioning of public sector organizations. The reason of these changes is a shift from the administration paradigm to the management paradigm as well as appreciation 
of the entrepreneurial activities of public organizations. These tendencies contribute to the transfer of management instruments used so far in the private sector to the public sector. The contemporary organisations, functioning in a turbulent environment, face the need to meet many complex requirements, which demands continuous adaptation to changes. The current reality, expressed in the marketization of many public sector services, indicates different way of managing public organisation.

Taking actions aimed at greater use of strategic management instruments in order to improve the performance of the organization providing social services, may lead to raising the efficiency of these organizations and thus bring significant economic impact to both the state and society. The need of changing how public organizations are managed, resulting from changes in the environment, is not always reflected in the on-going management practices. Philosophy of survival, cultivated for many years and typical for public organisations, strongly determines the unwillingness to take on entrepreneurial activity or take risk as confirmed in our study. Research results confirm popular opinions about the low level of strategic activity and orientation mainly on the culture of hierarchy as typical in public organizations (in our case District Labour Offices and Social Welfare Centres). The fact that Reactors prevail in the sample seems to confirm the aversion of public organizations managers to activities typical for the strategic management. Organizations with such strategic orientation generally have neither conscious nor a coherent strategy and represent relatively low propensity to change their behaviour. Managers follow principles of political rationality rather than economic efficiency and focus on short-term gains resulting from current needs of key stakeholders. The latter are usually those public entities that contribute to increasing the flow of public funds or have a direct or indirect impact on the development of career management in the entities providing social services. While large dependence on the environment does not raise major surprise in case of public organizations, the fact that they do not have strategy of functioning may be alarming. The second largest group are Defenders, exhibiting low level of entrepreneurship and innovation, also typical for many public sector organizations. The Defenders engage relatively low or do not engage at all in the development of new products or markets, while devoting much attention to improving the efficiency of their operations. In addition, they are characterized by centralized decision-making and usually have relatively simple control mechanisms.

Respondents indicate two organizational cultures as dominant, the clan and the hierarchy. Hierarchy oriented cultures are structured and controlled, 
with a focus on efficiency, stability and "doing things right." They often have well-defined policies, processes and procedures. Hierarchies value effective coordination and work organization, while hierarchical leaders are typically coordinators and organizers who keep a close eye on what is happening. The second dominant culture is clan. The Clan organization has less focus on structure and control and a greater concern for flexibility. Rather than strict rules and procedures, people are driven through vision, shared goals, outputs and outcomes. In contrast to Hierarchies, clans often have flat organizations and people and teams act more autonomously. Clan leaders act in a facilitative, supportive way and may take on a parental role.

What stems from our research results is that for the development of polish public organizations it is essential to create an organizational culture outwardly oriented, encouraging experimentation, innovation and flexibility, strengthening organizational learning and allowing to effectively identify and use opportunities arising in a dynamic environment. The results indicate, however, that the culture of many Polish public organizations providing social services is still characterized by strong inward focus, safety, predictability, consistency and order. Although these values are long appreciated in public organizations, they do not fully correspond to their present conditions of functioning. Existing culture is connected with hierarchy, centralization of decision-making, excessive formalization and rather insufficient flexibility of operation. Although nowadays employees in many public organizations have greater autonomy, research results show that the scope of the changes taking place in the organizational culture is still inadequate. What prevail in most organisations in question are hierarchies. Moreover, research results show that dominating culture is strong, with deeply rooted norms and values, which often make it difficult to transform. Hence, choosing appropriate methods and tools of managing cultural transformation is crucial. It is important not only to analyse and diagnose existing organizational culture, but also to analyse it antecedents and outcomes, as it may allow more conscious and deliberate shaping of future culture.

\title{
Summary
}

\begin{abstract}
Strategic Orientation and Organisational Culture in Polish Public Organisations: Insights from the Miles and Snow Typology Polish public organisations are often perceived as having strong bureaucratic orientation, avoiding both change and risk. However, in the last decade a distinct change in the management model of public organisations can be noticed. Public sector becomes an open
\end{abstract}


ground for mergers and partnerships, entrepreneurial leadership, diversified services and commercialization (Golensky and DeRuiter 1999; Zimmerman and Dart, 1998; Pollitt and Bouckaert, 2004; Walker, 2013]. Public organisations embrace these strategies from the for-profit sector in order to manage change and to be effective. Most importantly, public organisations are adopting these frameworks in order to survive the changing operating environment, including changes in the level of government funding. Our paper draws on the Miles and Snow (1978) typology of generic strategies - prospectors, defenders, analysers, and reactors - to identify different organisational strategies within public organisations providing social services in Poland. In order to assess organisational culture we used the most widespread and used in many empirical studies Cameron and Quinn's model (2003), the Competing Values Framework (CVF), from which four cultures - adhocracy, clan, market and hierarchy - emerge. The choice of these two providers of social services was dictated by our conviction, that these organisations are critical both for the national economy and for mitigating, counteracting and preventing social exclusion.

Keywords: strategy, strategic orientation, organisational culture, social services, Miles and Snow typology, public sector.

\section{Streszczenie}

Orientacja strategiczna i kultura organizacyjna w polskich organizacjach publicznych: wnioski płynące z typologii Miles'a i Snow'a

Polskie organizacje publiczne postrzega się często jako silnie zbiurokratyzowane, unikające zarówno zmian jak i podejmowania ryzyka. Jednakże, jak pokazuje ostatnia dekada, w modelu zarządzania organizacjami publicznymi zauważyć można pewne zmiany. Sektor publiczny staje się bardziej otwarty na kolaborację i kooperację, działanie w formule partnerstwa, przedsiębiorcze przywództwo oraz większe zróżnicowanie dostępnych usług (Golensky, DeRuiter 1999; Zimmerman, Dart, 1998; Pollitt, Bouckaert, 2004; Walker 2013). Zmiany te często inspirowane są zmianami mającymi miejsce $\mathrm{w}$ sekatorze non 
profit i mają umożliwić bardziej skuteczne ich wprowadzanie jak i większą efektywność organizacji. Co więcej, organizacje publiczne zmieniają strategie funkcjonowania także $\mathrm{z}$ uwagi na zmieniające się otoczenie, $\mathrm{w}$ tym na dostępność środków publicznych jako ich głównego źródła przychodów. Niniejszy artykuł bazuje na typologii orientacji strategicznej według R.E. Milesa i C.C. Snowa - poszukiwacz, analityk, obrońca, reagujący - celem identyfikacji orientacji strategicznej organizacji świadczących usługi społeczne w Polsce. Aby ocenić kulturę organizacyjną $\mathrm{w}$ badanych organizacjach wykorzystano powszechnie znany model wartości konkurujących Cameron'a i Quinn'a (2003) pozwalający na wyróżnienie czterech rodzajów kultury organizacyjnej - adhokracji, klanu, rynku i hierarchii. Wybór rodzajów podmiotów był podyktowany przeświadczeniem o krytycznym znaczeniu świadczonych $\mathrm{w}$ tych podmiotach usług społecznych zarówno dla gospodarki narodowej jak i dla łagodzenia, przeciwdziałania i zapobiegania problemom związanych z wykluczeniem i marginalizacją.

\section{Słowa}

kluczowe: $\quad$ strategia, orientacja strategiczna, kultura organizacyjna, ustugi spoteczne typologia Milesa i Snowa, sektor publiczny.

\section{References}

1. Azhar S.M. (2008), Strategic Orientation and Performance: The Case of Equifinality from a Developing Market Perspective, "The Business Review", Cambridge, Vol. 10(2), pp. 120-128.

2. Baird K., Harrison G., Reeve R. (2007), The Culture Of Australian Organisations And Its Relation With Strategy, "International Journal Of Business Studies", Vol. 15, No. 1, pp. 15-41.

3. Cameron K.S., Quinn R.E. (2003), Kultura organizacyjna - diagnoza i zmiana. Model wartości konkurujacych, Oficyna Ekonomiczna, Kraków.

4. Chow I.H.S., Liu S.S. (2009), The effect of aligning organisational culture and business strategy with HR systems on firm performance in Chinese enterprises, "The International Journal of Human Resource Management", Vol. 20, No. 11, pp. 2292-2310.

5. Courtney R. (2002), Strategic Management for Voluntary Nonprofit Organisations, Routledge, London.

6. DeSarbo W. S., Di Benedetto C.A., Song M., Sinha I., (2005), Revisiting the Miles and Snow strategic framework: uncovering interrelationships between 
strategic types, capabilities, environmental uncertainty, and firm performance, „Strategic Management Journal” , Vol. 26, Iss. 1, pp. 47-74.

7. Doty D.H., Glick W.H., Huber G. (1993), Fit, equifinality, and organisational effectiveness: a test of two configurational theories, „Academy of Management Journal", Vol. 36, No. 6, pp. 1196-1250.

8. Fang S., Wang J. (2006), Effects of Organisational Culture and Learning on Manufacturing Strategy Selection: An Empirical Study, „International Journal of Management", Vol. 23, No. 3, pp. 503-514.

9. Frumkin P., Andre-Clark A. (2000), When mission, markets, and politics collide: values and strategy in the nonprofit human services, "Nonprofit and Voluntary Sector Quarterly", No. 29 (1), pp. 141-161.

10. Gupta B. (2011), A comparative study of organisational strategy and culture across industry, "Benchmarking: An International Journal“, Vol. 18, No. 4, pp. 510-528.

11. Kaya N., Seyrek I.H. (2005), Performance impact of strategic orientation: evidence from Turkish manufacturing firms, "Journal of American Academy of Business", Vol. 6 (1), pp. 68-71.

12. Kieżun W. (2000), Transformacja administracji publicznej w świetle teorii organizacji i zarządzania, MBA, No. 1.

13. Miles R.E., Snow C.C. (1978) (2001), Organisational Strategies, Structure and Process, McGraw-Hill, New York.

14. Morgan R.E., Strong C.A. (2003), Business performance and dimensions of strategic orientation, "Journal of Business Research", Vol. 56, pp. 163-176.

15. Naranjo-Valencia J.C., Jimenez-Jimenez D., Sanz-Valle R. (2011), Innovation or imitation? The role of organisational culture, „Management Decision“, Vol. 49, No. 1, pp. 55-72.

16. O'Reilly C., Chapman K., Caldwell D. (1991), People and Organisational Culture: A Profil Comparizon to Assessing Person-Organisation Fit, "Academy of Management Journal“, September, pp. 487-516.

17. Pleshko L.P. (2006), Strategic orientation, organisational structure, and the associated effects on performance, "Journal of Financial Services Marketing", Vol. 12, No. 1, pp. 53-64.

18. Pleshko L.P., Nickerson I. (2008), Strategic orientation, organisational structure, and the associated effects on performance in industrial firms, "Academy of Strategic Management Journal", Vol. 7, pp. 95-110.

19. Porter M.E. (1992), Strategia konkurencji. Metody analizy sektorów i konkurentów, PWE, Warszawa.

20. Ring P., Perry J. (1985), Strategic management in public and private organisations: implications of distinctive context and constraints, "Academy of Management Review", No 2(10), pp. 276-286.

21. Sanchez A.A., Marin G.S. (2005), Strategic Orientation, Management Characteristics, and Performance: A Study of Spanish SMEs, "Journal of Small Business Management", Vol. 43(3), pp. 287-308. 
22. Schneider B., Schneider K. (2007), Aligning Culture, Strategy and Leadership, „Executive Forum", pp. 1-6.

23. Schwartz H., Davis S. (1981), Matching Corporate Culture and Business Strategy, "Organisational Dynamics”, Summer, pp. 30-48.

24. Skrzypek E. (2007), Kapitat intelektualny jako podstawa sukcesu w społeczeństwie wiedzy, „Problemy Jakości”, No. 1, pp. 4-7.

25. Snow C.C., Miles R.E., Miles G. (2005), A configurational approach to the integration of strategy and organisation research, "Strategic Organisation", Vol. 3, No. 4, pp. 431-439.

26. Stone M.M., Bigelow B., Crittenden W. (1999), Research on strategic management in nonprofit organisations, "Administration and Society", No. 31, pp. 378-424.

27. Wallach J.E. (1983), Individuals and Organisations: The Cultural Match, "Training and Development Journal", Vol. 37, No. 2, pp. 29-36.

28. Yarbrough L., Morgan N.A., Vorhiesd (2001), The impact of product market strategy-organisational culture fit on business performance, "Journal of the Academy of Marketing Science“, Vol. 39, pp. 555-573.

29. Zhou K.Z., Li C.B. (2007), How does strategic orientation matter in Chinese firms, "Asia Pasific Management", Vol. 14, pp. 447-466.

30. Conant J.S., Mokwa M.P., Varadarajan P.R. (1990), Strategic types, distinctive marketing competencies and orga- nizational performance: a multiple-measuresbased study, "Strategic Management Journal", Vol. 11, No. 5, pp. 365-383. 